\title{
Hail and Farewell! The Methodist Protestant Church in Iowa
}

\author{
(Concluded)
}

By R. E. HARVEY

The ERa OF SeParation

The scope of this article does not permit a detailed record of the activities of these two Conferences that for the next seventeen years functioned side by side, manifesting their brotherly love by the annual exchange of Fraternal Messengers, and the easy transfer of ministers to and fro across a boundary that appears quite flexible. The two bodies never drifted far apart. In the stress of the Civil War each vied with the other in support of the Union with soldiers, chaplains, nurses, money and prayers, to say nothing of aggressive conference resolutions breathing a spirit and a fervor that with a shifting in phraseology from domestic to foreign foes, would readily voice the loyal devotion of today to the cause of freedom and national security.

The records of the Iowa Conference for the next seventeen years are but partially preserved. It is true, however, that the Conference finally reversed itself on the tobacco issue which had appeared in the years past before the original Conference. The use of tobacco was banned for "gentlemen" in the Conference room first, and some years later tobacco users were barred from admission to the itinerant ministry, except upon a pledge of total abstinence therefrom. This, of course, initiated the movement for the final extinction of the habit among the regular clergy. Much of the credit for this action was due to the persistent efforts of the Reverend Samuel $\mathrm{N}$. Matheny, who, undiscouraged by opposition and defeat, waged the anti-tobacco war in both Iowa conferences until final success crowned his effort. ${ }^{29}$

20e Des Moines Sunday Register, June 28, 1942, "Family's 113 Years in Ministry Ended," account of Samuel Matheny and two preacher sons. 
The continuous careful protection of the individual cause for much debate and discussion at Annual Conference sessions did not stop in the new divisions of the origminister's right to correct an erring brother, often the inal Conference. Such for instance, the report of the trial of Francis A. Kirkpatrick on various charges, only one of which was sustained, accused him of the use of "Sinful words." For this he was sentenced to a rebuke by the president, "which admonition was given, and, I believe, kindly received."

In 1859 Iowa City was back on the North Iowa map with a church building valued at $\$ 1,200$, while a parsonage in the Iowa Circuit covering parts of Iowa and Poweshiek counties, showed a disposition to entrench for permanent occupation. A visit from the President of the newly organized Minnesota Conference of the Methodist Protestant Church was enjoyed during the year, and at his request, two northern tiers of Iowa counties were loaned to his conference. But his invitation to join forces in founding a school of higher learning was politely declined, for the debts of Ashland Seminary still remained as a fresh caution in their memories.

Other aspects reflecting a maturing church were the resolutions of the North Iowa Conference decrying ministerial participation in land speculations and other secular pursuits. These, apparently originating in the laity, opened the way for new exhortations for a larger liberality in providing for pastoral wants. The lay delegates were instructed to raise funds on their respective circuits to purchase a horse for President Patterson's use on his executive rounds. This was the last favor or distinction the venerable pioneer enjoyed, for he passed to his final reward before another North Conference meeting. ${ }^{30}$

Eighteen circuits, two more than was recorded in 1858 , appeared in the minutes of the North Iowa Conference of 1860. The statistics for that year showed 964 members,

30Besides the appropriate memorial services held in Patterson's honor at the 1860 session of his Conference, and the ordering of the preachment of a funeral discourse at each first quarterly meeting of the new year, a special collection was authorized for the benefit of his widowed wife.

County, 1901, 139; History of Wapello County (S. L. Clarke Publ. Co., 1914). 
seven Sunday Schools with 265 scholars. Fairbanks, in Buchanan County had erected a meeting house at a cost of $\$ 400$. That this increase of over 300 members in two years had not entirely eliminated the stringent need for better support of the ministry is indicated in the resolution which notified the circuits that the failure to pay the pledged support of their ministers, "the same as to a Merchant or any other business man," entitled him to release from the Charge, while failure on part of the minister to carry out the spirit of these financial regulations would subject him to Conference censure.

In 1861, the year the thundering clouds of war broke over a divided nation, the North Iowa Conference elected R. B. Groff to the office of secretary, a man whose delightful copperplate chirography and passion for completeness might well be the envy of all his successors. ${ }^{31}$

President J. J. Watson, who was elected to the State House of Representatives from Iowa County in 1861, reported that year that he had visited four circuits twice, thirteen once, and missed two on account of legislative duties. Of his promised salary of $\$ 339.50$ he received only $\$ 118.49$, "which leaves me in debt, or to use funds from other sources" observed the realistic president. Rather shabby treatment for a hardworked executive, considering that nine circuits paid their pastors in full and most of the others in the North Iowa Conference paid above fifty cents on the dollar.

A layman's resolution before this Conference, requiring the resumption of ministerial house to house visitation and supervision of Class Meetings, hints at a pastoral remissness in cultivation of the vineyard. A similar

\footnotetext{
31Richard B. Groff is described in the Betz $M s$. as "a very eccentric character : in later years he retired from the ministry and ran a small variety store in Marengo. Here he grew old and musty and his store dusty and antiqueated, but he always had candy and toys for the children."

As might be expected from such a penman as Groff and from his flowering vocabulary, he was also a poet of parts. Two of his productions appear in the record of 1863 , one a memorial to the Reverend Perry Canfield who died within the year, and the other journalized at the request of the Conference, a "Good-Bye to the Conference of $1863 . "$

'Tis sweet to grasp the friendly hand, and gaze upon the tearful eye; To feel we are a social band, still laboring for the cause on high!

To feel the tide of love to roll, the kindling fires of joy to glow ;

The living, sparkling, burning soul! though in this vale of care and woe!

And when from earth we're called to go, by friendly winds thus arisen,

May the sweet gales around us blow, while stacking sheaves in Heaven !
} 
resolution, aimed apparently at the frequent inquiries into disputes and contentions amongst the clergy, came very appropriately from Nicholas Rosenberger, whose two sons were headed for the ministry, constituting their father a most suitable promoter of good will amongst preachers. It was an admonition-request worthy of acceptance in any age: "Resolved, that it is the sense of this Conference, that Christian Ministers should love each other, and treat each other in a brotherly manner, never speaking an unfavorable word in a brother's absence."

The tides of civil war were recorded in "Gone to the Union Army" against the names of four of the twenty-six preachers on the roll.

The war spirit intensified in succeeding years as the North realized that the short war first anticipated would instead be long and bloody and cruel in its sacrifices. In 1863 this was expressed in the report on the "State of the Country," couched in the exuberant vertiage of Secretary R. B. Groff, which required that each preacher declare his attitude toward the Union cause in open Conference.

The labor of preaching services during the war is evident in Secretary Groff's own report when he came up for passage of character:

Report of the Superintendent of Clear Creek Circuit: To the Annual Conference of the Methodist Protestant Church, setting in Toledo, Sept. 11th, 1863. Under the Providence of God and the Wisdom of Conference, I was sent to the above circuit, and arrived 19th of September, 1862. I found the membership kind, affectionate, and devoted to the spread of Christian Holiness. I remained on the circuit 47 weeks, or 315 days; preached 275 sermons, organized six new Sunday Schools, 3 Home Missionary Societies, and added six members to the Church, making 98 in all. There are seven appointments on the work: Clyde, Edenville, Bear Grove, Spencer's Grove, Minerva, Marietta, making a three weeks circuit.

In 1864 the Report on the State of The Country closed with an exhortation probably incited by tales of fresh guerilla raids from the distracted state of Missouri, breathing fire and blood: "By all that is sacred on earth, or holy in heaven, let us do justice to our suffering country, 
by welcoming traitors with bloody hands to hospitable graves!'32

Other less gory resolutions and other than statistical reports occupied the time of the brethren also. After a noisy discussion in the Northern. Iowa Conference in 1864 it was finally adopted by rising vote that "the use of tobacco is injurious to the human system, and especially to the character and usefulness of Christian ministers."

Still other developments of perhaps greater significance occurred during the war years. In 1862 the admission of women to the ballot and to all local Society or Class offices brought quite a few good sisters to Annual Conferences as lay delegates. The almost inevitable consequence was that ministerial wives came to fill this position somewhat extensively. This practice at last aroused opposition voiced in Conference action. The opponents to such representation argued that such a procedure was a nullification of the cardinal Methodist Protestant principle of Equal Rights, i. e. equal ministerial and lay representation in Church councils. This position of the Conference, while not designed nor effective in barring feminine delegates, nevertheless kept the parsonage ladies off the roll.

More revolutionary than the movement which gave the women the ballot and representation at Annual Conference was the movement for an organic unification of all non-episcopal Methodism that took shape during the Civil War epoch. This movement began in 1859 with overtures from the Wesleyan Methodist Church, another divisionist offshoot of the parent Methodist Episcopal Church, made to the General Conference of the Methodist Protestant Church, and which were in turn presented to the Iowa Annual Conference the same year by the Reverend Daniel Cartwright, and heard there with favor. ${ }^{33}$ Discussions continued between the Methodist Protestants, the

\footnotetext{
32"Welcome traitors with bloody hands to hospitable graves!" was a paraphrase from the famous speech of Rep. Thomas Corwin of Ohio opposing the war with from the famous speech of Ras later Minister to Mexico 1861-1864.

3Daniel Cartwright, like his brother Barton $\mathbf{H}$. Cartwright, the first $M$. E. Preacher at Burlington, Iowa, was an Iowa pioneer of that era. He joined the Wesleyan Methodist Church during the slavery controversy, and merged with the Methodist Protestant Church in 1866 . He served several appointments, seemingly all in the vicinity of Mt. Pleasant. See Waring, History of the Iowa Annual Conference of the Methodist Episcopal Church, and Minutes of the Iowa Conference of the Methodist Protestant Church.
} 
Wesleyan Methodists, the Independent Methodists, and Free Methodists for a number of years, finally culminating in a general agreement to combine forces under the name of The Methodist Church. This act of union took place in 1866, the two Iowa Conferences approving the change and modifying their church name accordingly. ${ }^{34}$

Only a few visible signs accompanied this attempted fusion. "Pastor" replaced the name of Superintendent as the title of the minister in charge of a circuit. "Stationing Committee" became "Committee on Pastoral Relations ," and the term of pastoral services was greatly extended. Most important change of all, and one which might have been presaged by the action of 1862 , was the admission of women to the ministry and hence to Conference membership. This did not result in large influx of feminists into the ministry at any one time, but the accordance of the right was, by itself, a most conspicious advance. Mrs. Pauline Martindale was the first woman admitted to Conference membership (Iowa Conference), in 1872. She served as co-pastor with her husband on several charges, and as an evangelist finally removed with him to Kansas.

A brief effort seems to have been put forth at the time of the union of the non-episcopal Methodist churches in Iowa to resurrect Ashland Seminary. In 1866 the North Iowa Conference received word that the sister body was now repossessed of that institution, free of debt, with a request that their northern neighbor aid in the support of that school by scholars and by funds. Accordingly, the Conference pledged co-operation and advised preachers and members alike to assist with money and students rather than patronize schools under other than Methodist Protestant auspices. Absence of Conference records for the following year leaves uncertain the effectiveness of the revival, but from 1868 on no mention is made of Ashland Seminary or Ashland Academy, hence it may be assumed the effort died a-borning.

More encouraging to the cause of higher education

${ }^{34} \mathrm{Cf}$. Bassett, chps. 44-50. The union of 1866 was only partially complete. 
than the Ashland enterprise were the tidings that The Methodist Church had acquired ownership of Adrian College, Adrian, Michigan, with such assets and prospects as to assure its successful operation. To this outstanding institution both the Iowa conferences gave their unqualified endorsement, cordially welcoming its financial representative, Joel S. Thrapp, to their pulpits and their resources of membership. Their patronage of Adrian College continued until late in the Nineteenth Century.

But during the years since 1858 not all proved well with the Northern Iowa Conference. Beginning in 1858 with sixteen circuits, we have seen where two years later eighteen were listed in the reports, with an increase of 300 in membership. However, in 1863 only fifteen circuits were listed, despite the presence of twenty-eight names on the ministerial roll. The old difficulty of obtaining sufficient numbers of capable men for the service of such meagerly supporting areas is possibly the occasion for the resolution of Rosenberger at the 1863 Conference:

Whereas, the life and prosperity of the Church, in great measure depends on the efficiency of the itinerant ministry;

Resolved, That it is the sense of this Conference, that no minister shall be received into the itinerancy, unless he intends to be effective immediately.

A resolution adopted after "much discussion."

Internal difficulties likewise appeared to have developed. One of the leading circuits of the northern conference suffered from the machinations of a pastor, who having been passed to the unstationed list, apparently in his absence, remained on the charge and systematically stirred up trouble. Another field, one of the most promising in the territory, suffered in like manner through the insubordination of a pastor who refused obedience to the mandate of the Committee on Pastoral Relations removing him to another field, declaring that being subject to neither Bishop nor Presiding Elder, he did not have to submit to Conference dictation. Of course other causes not appearing on the records may have operated to like disadvantage of the church. 
In 1873, the last year for which there are complete minutes, only seven ministers and three laymen answered Roll Call, although others are named as being present during the sessions. Of the 973 members reported, over onefourth were on the Peoria Circuit. Only nine charges reported salaries paid, five of them badly deficient. The highest salary was $\$ 531.95$ at West Liberty, while the Colo Mission stood lowest, with only $\$ 81.64$ paid. Nine churches and five parsonages were valued at $\$ 20,100$. Seventeen Sunday Schools reported 819 officers, teachers and scholars. Yet in that year fourteen ministers were assigned appointments, three were left to be employed by the president, and five circuits left to be supplied.

The Journal of Minutes for the North Iowa Conference is incomplete for the following year, with no statistics nor pastoral appointments being listed. The veteran Francis A. Kirkpatrick was, however, elected President, and delegates chosen to the General Conference of The Methodist Church to meet at Princeton, Illinois, in May, 1875. Although the next Annual Conference was designated to meet in Tipton in October, 1875, there the record ends. On the succeeding page is inscribed, "The North Iowa Conference was re-united with the Iowa Conference, at Hixon's Grove, Sept. 1, 1875. See Minutes of Iowa Conference, 1875, (signed) W. H. Betz."35

There are a number of unexplained features of this reunion. In the minutes of the Iowa Conference Josiah Selby is named as the President of the North Iowa Conference, with no mention of Kirkpatrick's resignation. No reference is made in either conference journal of preliminary negotiations looking toward the merger. The Betz entry merely states the fact, and is not an explanation. The sole documentary statement relating to the whole affair available is confined to a three line entry in the Iowa Conference journal for September 1, 1875: "It was moved that the Iowa Conference ratify the action of the late General Conference, (See General Conference Minutes

${ }^{85}$ Hixon's Grove was in Buena Vista Twp., Jasper County, southeast of Newton. 
Document K, Item 5.) Adopted." Immediately after this vote the President was directed to appoint a Committee to "notify the North Iowa Conference of our action of ratification." The latter body was evidently waiting in the Church while the matter was discussed by the Iowa Conference in the nearby school house.

As a matter of fact, the causes for separation, however potent in 1858, were no longer operative in 1875 . The differences caused by the slavery agitations had been settled first by action of the General Conference, and later and finally by the halocaust of the Civil War. Transportation facilities had largely removed the difficulties of travel. And it was logical that the re-union should have been a return of the Northern to the original Iowa Conference, for the southern Conference had been enjoying steady gains through the years. Their journal of 1874 reported the erection of six new churches, and several parsonages under construction. Revival interests were quite general throughout the district, and the opening of missions in Audubon, Pottawattamie and Harrison counties testified to expansive energy.

The Reunited Conference reported in $\mathbf{1 8 7 5}$ forty-four circuits, stations and missions, having 3,575 members of whom 654 were new accessions; twenty-six churches and seventeen parsonages valued at over $\$ 60,000$. And with only trifling debts, there was evidence of permanency. Thirty-six pastors were stationed, and twenty-one unstationed, besides, the Conference listed twenty-two local preachers, eighty-eight Sunday Schools containing 4200 scholars cared for by 452 officers and teachers. Missionary, education, and other benevolent collections totalling $\$ 1200$ indicated a fair degree of interest in kingdom building outside their own borders.

The old and familiar problem of ministerial support showed some improvement over conditions earlier prevailing. Pastoral salaries reported ranged from $\$ 775$ paid by the Newton Circuit, to eight paying $\$ 500$ or more, seventeen from $\$ 200$ to $\$ 475$, and the remainder falling below the two hundred mark. The redeeming fea- 
ture, however, of these last was that the more meagre salaries were supplemented by grants from the Conference Church Extension Board.

\section{Denominational ReUnion}

Scarcely had the Iowa Conference readjusted itself as a State wide unit when it was called upon to participate in the re-union of the two wings of their church. This was the first instance, the writer believes, in which denominations disrupted by the slavery issue in the pre-Civil War days welded anew the bonds of Christian affection. This event transpired in $1877 .^{36}$

The Iowa people having already disposed of their own little differences on the score of reunion, the larger movement produced but slight effect upon their organization, save that of restoring to the re-united Church the old and familiar name of The Methodist Protestant Church in place of the eleven year old The Methodist Church. The shorter name was thus laid on the shelf for three score years, until brought out and applied to the vaster unification whereby eight million of John Wesley's spiritual heirs assembled themselves within one fold in 1939. A consummation, it should be noted, the smaller Methodist denomination had labored and prayed for long years before there seemed any good prospect that it would ever be realized.

Indications of the leanings of the reunited Methodist Protestant Church towards a larger church union may be noted in the memorial addressed by the Iowa Conference in 1880, advising the Methodist Protestant General Conference, then considering publication of a new hymn book, to adopt the recently issued Methodist Episcopal hymnal, if possible to do so on an economical basis, with the Methodist Protestant imprint on the title page. Besides the regular dispatch of cordial greetings between the separate conferences, mutual transfers of ministers across the denomination barriers took place with little more formality than attended such exchanges from one Conference to another within those boundaries.

soBassett, chps, 51-53. 
One such migration from Church to Church was the Reverend Harry H. Workman, who in the late 1860's entered the Iowa Methodist Protestant Conference from the Methodist Episcopal ranks, and almost immediately took influential part in its activities, being advanced to the post of Secretary of the Conference, which post he continued to hold until his decease. Some decades later there came into the Des Moines Conference of the Methodist Episcopal Church, as though in exchange, one of the most promising of the younger ministers of the other denomination, Robert C. F. Chambers, who gave sixteen years of most acceptable service in his adopted Church. His memory is cherished by the writer of this article as a sympathetic personal friend.

With the reunion of the northern and southern branches of the church nationally the Iowa Conference of the Methodist Protestant Church may be said to have emerged into the modern era. That portion of Iowa in which the Conference functioned had itself experienced the transition from pioneer to settled existence, and the Church, being merely a cross section of its environment, naturally shared the common experience. There continued to be growth in the Conference, manifest in the formation of new fields of labor, at Dexter, in Monona County, and notably in the flourishing circuit called "Bass Lake," located near Winnebago City, Minnesota, which petitioned itself into the watchful care of the Iowa Conference. Yet the church was never able to successfully establish itself in the larger urban centers of the state. It remained almost exclusively a rural church, composed of generous circuits with numerous charges thereon.

Its inability to establish itself in the larger towns of the state was certainly not due to lack of will. Indeed the chief energies of the Conference appeared to be devoted during the later years to the needs of the "Home Extension Board" and educational enterprises. In $1876 \$ 100$ was subscribed by the Conference to assist in the erection of a church building in Osage. A few years later the long intermittant and partially successful efforts of William 
Remsberg and J. F. Rouse to found a permanent and stationed church in Des Moines drew most of the attention of the Home Extension Board. Special efforts were made to collect funds from other established circuits and missions to forward the enterprise. In 1880 a lot was purchased for $\$ 500$ upon which a building of $\$ 3000$ was contemplated. This Des Moines field, begun by the Reverend and Mrs. Remsberg in 1856, reported ninety-four members in 1892, seventy-three of whom had been gathered during the preceding year. By this time, however, the long talked of building had been erected at a cost of $\$ 3500$, and was announced to be clear of debt. Nevertheless, by 1900 the membership had dwindled to fifty, with a Sunday School of fifty-five. Pastoral support was so far below the level of comfortable maintenance that the president reported himself obliged to leave that church without a pastor for eight months of the year. Succeeding years brought no improvement, rather the reverse, and in 1904 the property was sold.

Sadly similar was the history of another earnest attempt to establish a Methodist Protestant Church in South Ottumwa, where the neglected territory was first entered by way of evangelistic services and a church organized, lots purchased and church erected at a cost of $\$ 4500$. For several years the work promised well, and was served by an excellent quality of pastors, besides having as a superannuated assistant pastor one who had been an outstanding leader of the Conference. Yet here also adverse conditions prevailed; memberships diminished, and not far from the date of the withdrawal from Des Moines a local merger was effected whereby the South Ottumwa Church joined with a small Congregationalist church to their mutual advantage.

A subsequent effort was made in Keokuk, with more permanent results. A still more recent enterprise was a church in the industrial part of Newton, which had been a strong center for the denomination. While proving financially burdensome to the Conference the church continues to this day. 
Both the Des Moines and the Ottumwa undertakings were largely financed by $\mathrm{J}$. W. Murphy, ${ }^{37}$ of Jasper County, one of those God's Noblemen whose presence in any congregation or denomination counts for more than half of our noisy preaching. This good man first entered the ranks in 1869, when as Conference Steward he produced a set of statistical reports that marked a permanent advance, and became a model for all his successors in that office. Elected Secretary of the Conference on the passing of the Reverend Harry $\mathrm{H}$. Workman, he was continued in that office for thirty years, dying at the seat of Conference. For nearly all that period he was re-elected by acclamation annually, and served on all the committees having to do with the financial interests of the Conference. Besides this, he represented the local body in numerous sessions of the General Conference, where his counsels and judgment rated with those of the great church leaders, both ministerial and lay.

Although efforts continued throughout the entire life of the Methodist Protestant church to establish itself in the sizable cities of Iowa, with the possible exceptions noted, it never quite succeeded. The reason was largely that of finances. To the earnest and regular appeals of the Committees on Home Extension for the solicitation and collection of adequate funds for the furtherance of its work by the clergy, the reports of sums collected tell a sorrowful story of pittances and tokens of the amounts necessary to effectively accomplish the work: This lack of finances was in part traceable to the small struggling membership of the typical Methodist Protestant country church, which seldom was able to pay its pastor more than $\$ 600$ at most, and more frequently too much less. It was a case of present necessity being deemed greater than distant need.

During the last quarter of the century much attention was laid upon the educational advancement of the Methodist Protestant ministry and the denominational

\footnotetext{
37W. H. Betz was also concerned in both enterprises, at Ottumwa as an officer in a Layman's Bureau which sponsored the undertaking, at Des Moines he served as the last pastor appointed by the Conference. For accounts of Murphy see the Betz $M s$.
} 
schools of that order. As early as 1862 the Conference Committee on "Wants of the Church" listed as one of the most important wants "an educated ministry." That same year the committee on Ways and Means brought forth a formidable report of subjects which it recommended that all candidates for the ministry study "to become acquainted with."38 This, compared with the list of qualifications submitted in 1858 , shows a trend toward a secularization of knowledge noticeable during these years. In 1882 the Conference Committee on Ministerial Education approved the report of the year before and submitted it as still the thought of the Committee, "that every minister should have a good literary education at least." The Committee was particularly pleased to report that in the existence of three denominational colleges, the nearest of which was Adrian, Michigan, the Methodist Protestant Church "now posesses all the facilities necessary to render aid to all who seek these attainments."

Four years later the Iowa Conference endorsed the three year theological curriculum pursued at Adrian College, and recommended that. such be "the course to be pursued by all our candidates for the ministry. Also that as many of our young men now in the ministry as can, pursue these studies on the Chautauqua plan, as proposed by the Faculty of the College."

'That the subject of a trained and educated ministry was a close and earnest interest of the clergy is the evidence of the frequent recurrence to studies in the regular Conference reports. In 1883 "candidates for the itinerancy" were required to show a mastery of "English Grammar, Geography, History of the United States, Elementary Rhetoric and Logic, Doctrines of the Bible, History and Polity of the Methodist Protestant Church." An even more forbidding list was the schedule of which mastery was desired of those candidates for ordination. ${ }^{39}$

\footnotetext{
${ }^{88}$ Stressing language and grammar, ministerial candidates were recommended to begin "first with English, then the Latin, and if possible the Greek and Hebrew. And in the next place Mathematics: Commencing with Mental Arithmetic; Practical Arithmetic; Algebra; Trigonometzy; Surveying; The Higher Mathematics: History : study particularly all the history immediately connected with the great cause of God upon the earth, both of antient [sic] and modern date. Antient and modern Geography."

${ }^{39}$ Text books assigned included Lee, Systematic Theology, Phelps, Homiletics,
} 
With pardonable denominational pride and insistence, the Conference was likewise regularly placed on record urging the subscription to denominational literature of the Church, published by Church presses at Pittsburgh and Baltimore. The Little Protestant of the sixties, giving way to the Morning Guide for Sunday School scholars, and the Western Protestant Record being the chief of the adult journals.

In keeping with the attention given to Sunday Schools, which the Church endorsed as a conservator of the denomination and as a guide in its precepts, was the continued lament at the neglect of the keeping of the Sabbath. In 1876 the Conference Committee deplored the operation of beer gardens and Sunday excursions in all forms, lamented that even church people were assembling "themselves together or running around visiting-reading the secular papers, talking Politics, Hogs, and Cattle, in short, anything and everything but Jesus and his Love." This neglect of the day was attributed in 1880 to "foreign rationalism and the apathy of parents" as well the neglect of the pulpits to urge a more proper observance. Three years later the Conference went on record decrying the employment of men by the railroads on Sundays.

The Church was also much exercised over the question of temperance, regularly taking stout resolutions condeming the traffic in liquors as the work of Satan and his hosts, and staunchly supporting efforts leading toward a state-wide prohibitory law.

Yet there were other events of more than passing interest which transpired during the latter part of the century. With the granting of the franchise and rights of office to the church womanhood, already mentioned, there came in time the admission of women to the ministry. The first of these, Mrs. Pauline Martindale, was received by the Iowa Conference in 1872. Others found place from time to time, usually as evangelists, although

Barrows, Sacred Geography and Antiquities, Horne Introduction, Porter, Mental Science, plus a written sermon for the first year. Church History by Fisher, to the Reformation and Hoppin's Pastoral Theology were new studies for the second year. The third year, while continuing the written sermon and systematic theology, introduced Shedd, History of Doctrine, and Paley, Natural Theology. 
two of them, Mrs. N. D. Whitehead, and Mrs. E. M. Remington, were pastors of Churches in their own right and assumed their full share of business activitieis in the conference sessions.

The Founding Fathers of the Iowa Conference were thinning their ranks. In 1892 Robert Miller, the last charter member of the original Iowa Conference passed away. Four years later, one year after he had delivered the semicentennial address, William Remsbergh, also a veteran of the Church crossed the Great Divide.

At the end of the century the Conference comprised thirty-three pastoral charges, had forty-seven ministerial members, 3551 on the membership rolls. Sunday Schools numbered but seventy-six, with 671 officers and teachers and 3437 scholars. Seventy-five church buildings and twenty-five parsonages had a total valuation of $\$ 112,700$. Debts amounted to $\$ 1912$, or less than two percent on the building valuations, an example of conservative finance worthy of imitation by all corporate bodies, secular and sacred.

Yet the condition of the denomination in 1900 showed that it had remained almost static since the opening of the era begun with the denominational reunion. Seventy Sunday Schools were reported in 1876 . In 1885 there had been 2969 members on the rolls, and a year later 3134 . Thus, although in the fifteen years since 1885 the valuation of church property had doubled, membership and churchly activities plainly had not.

In 1900 salaries of the clergy had improved somewhat over that of 1886, but not markedly. In the latter year the highest salary received was $\$ 510$, the lowest $\$ 73$, with the average mean salary $\$ 300$. At the turn of the century two charges were paying $\$ 700$ or more, nine from $\$ 500$ to $\$ 672$; sixteen from $\$ 300$ to $\$ 476$; two paying $\$ 235$ and $\$ 237$, one $\$ 184$, and East Des Moines, $\$ 171.50$. As a redeeming feature in the latter year it must be noted that only a few deficits are listed in a total ministerial budget of $\$ 12,513$. Nonetheless, the fact that the total giving for all purposes named amounted to but little more than 
$\$ 6$ per capita for the year, indicates a very limited measure of liberality toward their own 'spiritual interests on the part of the Church constituency.

\section{The Twentieth Century}

- The perennial interest of the denomination in education was evidenced in the attention given to another institutional development at the turn of the century. The Kansas City University, sponsored by all the western Conferences of the Methodist Protestant Church at that time, diverted the support hitherto given by the Iowa Conference to Adrian College. In this later enterprise some of the leading ministers of the Conference were enlisted, and to which they loaned, without much authority, the Conference Church Extension funds, only to have them disappear in the collapse of the institution shortly thereafter.

About the same time proposals for organic union with other Methodist denominations, the Congregationalists, the United Brethren and others, induced a state of uncertainty in the ranks of the Church that could not but stagnate aggresive efforts to a large extent. On top of this there were serious internal disturbances emanating from doctrinal disputes over Christian Perfection, or Entire Sanctification, in which congregations were divided into factions and ministers alienated, sadly demonstrating, a'lack of the very thing over which they contended.

With all these adverse influences at work, it is small wonder that by the middle of the first decade, a decided slump manifested itself in Conference records, pastoral charges vanishing from the list, ministerial ranks shrinking, and membership declining. Another factor undoubtedly at work was the immense prosperity attending that period. Farmers, among whom the church had its greatest strength, were tempted to exchange their highly appreciated Iowa holdings for cheaper lands, or retire to towns and cities where no churches of the sect flourished, or remove to enjoy the fruits of toil in a more genial clime.

Rising revival tides, late in the decade, in part compensated the Conference for its losses, yet the year 1910 
found but 24 charges in the list of appointments, with a total lay membership of but 3009. Only eighteen of the charges were supplied with pastors, while of eleven additional ministers on the roll, but two were available for vacant fields.

More encouraging, however, was the marked decrease in Conference trials, these being almost exclusively restricted to necessary discipline for moral lapses, usually adjusted by the voluntary withdrawal of guilty persons. The period of financial prosperity during this decade, moreover, one of the most comfortable in Iowa's economic history, manifested itself in better salaries and increased investments in church properties, four pastors receiving $\$ 800$ a year or more, and the lowest, a supply, $\$ 177.48$.

Some of the strangling uncertainties of the first ten years of the century disappeared during the second as all projects of a larger church union were dismissed or forgotten except the final union of 1939.

Along with this came a tendency toward fewer and stronger churches. During the inflationary period of the first World War weak congregations could not possibly exist, while the stronger ones became more able to meet their obligations and needs. In this period also passed away most if not all of the mighty men of the pioneering era of the faith, the heroic era, whose lives and memories linked back to the founding days of the Conference. The Conference was left in the hands of men still living and therefore inappropriate subjects for present evaluation.

Midway in the next ten year cycle came the merger by mutual agreement of the Iowa and the North Missouri conferences, accomplished in 1915 to the satisfaction of the contracting parties and ratified by the General Conference in May, 1916. This action well might write finis to this historical sketch but for the fact that the southern addition existed more in token than substantial being, leaving the Iowa increment as the main factor in the partnership.

The immediate results of this union of conferences were encouraging, as indicated by the statistics of 1918- 
the last to be entered in the ancient long-hand ledger purchased in 1858-which gave the records of forty pastoral charges, 8 of them in Misouri. Twenty-six lay delegates were in attendance, leaving fourteen parishes unrepresented. Still the laity could have had things their own way, since of the thirty-one ministers listed, ten were starred as. "Not Present during Session." In the figures of 1918 sixty-three organized Classes were reported; seventy-five church buildings, valued at $\$ 210,100$ with indebtedness of barely $\$ 5310$, and converts of 417 for the preceding year were other figures in the report. After deducting 153 members as "withdrawn or discontinued" a total membership of 4872 was left. Not a great increase over the report of 1900 .

With the farm deflation of the early 1920's there set in another church depression, felt throughout the Middle West by all denominations, and especially disastrous to one whose constituency was so largely located in the rural districts and smaller towns. The decline was not checked for several years, and then but partially recovered. The membership in 1928 was but 3700, although church property figures reached an all time high of $\$ 262,000$, of which sum $\$ 47,000$ was invested in parsonages.

The last ten years of the existence of the Iowa-Missouri Conference of the Methodist Protestant Church was so largely devoted to negotiations for a Methodist union on a grand scale, the field for which consultations lay entirely outside this area, that little is left to record, aside from the establishment of the Newton Church, dedicated in 1932.

The minutes for the last session of the denomination, held September 12-13, 1939, list twenty-one pastoral charges in Iowa, which, with the pastors assigned for the ensuing year were as follows:

Attica, E. W. Meier.

Bussey, E. H. Finch.

Farrar, H. B. Fay.

Hixon Grove, W. H. Betz.

Keokuk, 12th Street, A. A. Smith.

Keswick, to be supplied. 
Ladora, H. E. Williams.

Marne, Peter Trucano.

Mt. Zion Circuit, Ben Spurlock.

New London, Elm Street, W. W. Steinmetz.

Newton, Community Heights, W. H. Betz.

Ohio Circuit, R. H. Kettell.

Osceola Circuit, to be supplied.

Ottumwa, Riverview, to be supplied.

Osceola, Trinity, W. Y. Cole.

Peoria, H. B. Fay.

Millersburg, J. A. Harp.

Zion Hill and South Prairie, to be supplied.

These stations and churches were incorporated in the Iowa-Des Moines Conference of the united Methodist Church. Rhodes, with C. R. Green, pastor, and Spring Grove, to be supplied, went by reason of geography into the Upper Iowa Conference. Thus showing again how predominantly south-eastern was the strength of the Methodist Protestants in Iowa.

Of eleven charges located in Missouri, only three had pastors appointed, two of them served by the same man. W. M. Martin, E. P. Spurlock, Mrs. Pearl Spurlock, R. Underwood, J. N. Waterman, Glenn Parrott, and D. E. Arnold were left without appointments, and were suitably placed under the new regime.

In material assets-not distinguishing by state linesthis old Iowa-North Missouri Conference contributed to the new dispensation 47 churches valued at $\$ 213,300$, all free of debt except Community Heights, Newton, which bore the burden of $\$ 25,000$. Sixteen parsonages, worth $\$ 30,700$, carried debts on two of them totalling $\$ 1936$. There were 3572 church members reported in the last meeting; forty-five Sunday Schools enrolled 2689 scholars; fifteen Christian Endeavor Societies had 367 members; sixteen Woman's Missionary Auxiliaries, 262 members; twenty-six Ladies Aid Societies, 698 members. Annual and General Conference benevolent collections totalled $\$ 3477$, while for pastoral support and all other items of local church expense, $\$ 21,399$ was reported, a grand total of $\$ 25,017$. The average contribution was $\$ 7.18$ per member. 
New London, a pioneer Methodist Protestant stronghold, and scene of many previous annual gatherings, entertained this final assembly. H. E. Williams was President, W. H. Betz secretary. With the entire proceedings directed to the dissolution of the ties that had bound this group of Christian workers hitherto, the atmosphere must have been pervaded with feeling in which some of the closing sentences of the President's Annual Report touched responsive chords: "Let us remember that, in the New Order, as always, success wil come with hard work and sound preaching. Let us carry on with confidence and wait on God for direction and his Blessing on all plans for the work .... Let us look forward to the New Contacts, and the New Fellowship, in the larger field, assured that everything that is done for God shall last forever."

With this valedictory the little band adjourned the Iowa Methodist Protestant Conference sine die, and wended their way to Burlington, where the Iowa-Des Moines Conference accorded them a cordial welcome into the "New Fellowship" of which President Williams spoke so hopefully.

Nor did they come as strangers to strange situations. Most of the reforms for which their founding fathers had contended so in vain 110 years before had been so long embodied in general policy of the Methodist church that one of the Methodist Protestant church could utter the pleasantry, "The Episcopal Methodists have all come over to our side, and so we kindly consent to take them in !"

Let us see the basis for this little jest. Equal Rights of Laity with Ministry in church government had obtained in both the larger Methodist branches for more than seventy years, not only in Annual and General Conference, but on all church boards and in all church institutions. Women, first granted the right of ballot and office in this body, and later admitted to the ministry, came into their own so long ago in the Methodist Episcopal Church that perhaps none now living can recall the day when a "Woman Preacher" was a novelty. Several years before 
the parent church relinquished its tenacious insistence upon the two year pastoral term, Methodist Protestant preachers were being appointed for three successive years. About the time the Methodist Epicopal Church adopted the three year limit, Methodist Protestant preachers in special cases were allowed longer terms; and the Methodist Episcopal extension to five years was matched by the younger church by a removal of all limits, so long as pastor and people could agree. And whatever of arbitrary power may have been reposed in, or assumed by Bishops and Presiding Elders in the ancient past, their authority had long ago become more advisory than mandatory, although still clothed with supervisory duties which furnish the church with an efficient superintendency so often painfully lacking in Methodist Protestant administration. This was so thoroughly recognized by the latter church that about forty years ago it found it expedient to permit a five year term in office in he conference presidency. Other instances might be quoted in which the smaller body acted as proving ground for principles subsequently accepted and applied by the larger bodies, both North and South, but these are sufficient to demonstrate the degree in which this sister group, numbering but 2.5 per cent of the grand total, acted as a leavening agency upon the other constituent elements of what is now United Methodism.

And so the course of history had come full circle again. In this day of a more democratic and tolerant understanding among all faiths, it is most fitting that the branches of the largest single Protestant denomination should harmonize their services, and join to prosecute their work of Christian teaching and living. While it is Hail to the Union it is truly Hail and Farewell to the Methodist Protestant Church.

The Rev. R. E. Harvey, Des Moines, Iowa, is Conference Historian of the Iowa-Des Moines Conference of the Methodist Church. He has contributed other articles on church history to THE ANNALS OF IOWA. 
Copyright of Annals of Iowa is the property of State of Iowa, by \& through the State Historical Society of Iowa and its content may not be copied or emailed to multiple sites or posted to a listserv without the copyright holder's express written permission. However, users may print, download, or email articles for individual use. 